\title{
Negotiating the Space of Civil Autonomy in Hong Kong: Power, Discourses and Dramaturgical Representations
}

\author{
Agnes S. Ku
}

ABSTRACT This article delineates the negotiated space of civil autonomy in post-handover Hong Kong through the contingent interplay of law, discourse, dramaturgy and politics. It takes the Public Order Ordinance dispute in 2000 as the first major test case of civil conflicts in the shadow of the right of abode struggle. As it unfolded, the event demonstrated both the power and limits of resistance by the people, and the government's increasing will, as well as the strategies it used, to rule within the "law and order" framework under continual challenges. In the event, civil autonomy had been a contested issue involving considerations of rule of law, rights, civic propriety, state legitimacy and the construction of particular identity (such as student-hood). Given the multiplicity of discourses and sub-discourses, citizenship practices and public criticisms opened up a contested space for resistance and negotiation. A campaign of civil disobedience was at first successfully mounted through an ensemble of political and symbolic mechanisms. A turning point was configured when, mediated by a meaning reconstruction process, the government made a series of political and performative acts to re-script the drama, which turned out to be an ironic success for itself that put state-society relations on an increasingly tenuous course. Ultimately ideological differences were at stake: respect for a rights-based discourse of rule of law versus the assertion of political and legal authoritarianism.

In Hong Kong, the transitional period between 1984 and 1997 witnessed a shift from a colonial ideology of "law and order" to a more rights-based discourse of "rule of law" under British rule. After 1989, in a context where the pace of democratic reform would be circumscribed by the Basic Law, the rule of law discourse was instituted to conjecture the possibility of rights under political authoritarianism for post-handover Hong Kong. ${ }^{1}$ This was a precarious course to take, and in the final transitional years the row between Beijing and London over Governor Patten's reform proposals only cast a bigger shadow over the prospects of rights development. It might therefore come as no surprise that after the handover the "law and order" discourse is being re-asserted as a ruling framework under the SAR government. This development, albeit not entirely unanticipated, is nevertheless much resisted now that a stronger sense of rights consciousness has emerged among the people. The event over the Public Order Ordinance in 2000, which involved a campaign of civil disobedience against the law, presented the first major conflict over the question of civil rights, coming amidst increasing state-society tensions over the issues of law, right and constitutionality after the right of

1. See Brian Hook and Miguel S. Neves, "The role of Hong Kong and Macau in China's relations with Europe," The China Quarterly, No. 169 (2002), pp. 108-135.

(c) The China Quarterly, 2004 
abode controversy. If the resistance movement in 2000 was seen as achieving relatively limited political success in the end, as compared to the much more dramatic effects of the huge demonstrations against the national security legislation more recently in July 2003, the whole 2000 dispute nevertheless was both revealing and constitutive of the changing state-society relationships that were yet to unfold.

The dispute in 2000 broke out "by accident," but as it developed it demonstrated both the power and limits of resistance by the people, and the government's increasing will, as well as the strategies it used, to rule within the "law and order" framework under continual challenges. In this article, it is proposed that the event presented an instance whereby the boundary of civil autonomy was tested through the interplay between state power and citizenship practice, and between discourse and dramaturgy. Under the competing discourses (and sub-discourses), civil space was negotiated through a symbolic process of meaning construction and reconstruction of student-hood, street activism and civic propriety in the public sphere on the one hand, and a series of political and performative acts to script and re-script the drama by the contenders and the government on the other. Two specific questions are pertinent. First, how and why was the pro-rights alliance first able to present a successful dramaturgy of legitimate resistance (with a campaign of civil disobedience) around the discourses of rights and rule of law in order to expand the scope of civil autonomy beyond legal confines? Secondly, how, and with what political and symbolic effects, did the state later present a dramaturgy of restoration of "law and order" that delimited civil space $?^{2}$

The idea of dramaturgy bespeaks a distinctive understanding of political action as staged or performative practices, which engage meaning with the public through scripting, role enactment and other accompanying symbolic expressions. ${ }^{3}$ Scholars in China studies have applied this approach to study the 1989 Beijing student movement. ${ }^{4}$ Following and extending this line of research, this discursive-dramaturgical approach to civil struggle looks at the roles of the contenders, the state and the public (including the media), and emphasizes relative fluidity within the field of possibilities and constraints. It explains how the interplay among dis-

2. The empirical analysis is based primarily on documentary materials from four local newspapers, and supplemented with the internal documents of the Hong Kong Federation of Students and interviews with the student leaders.

3. Jeffrey C. Alexander, "Symbolic action in theory and practice," unpublished manuscript, 2001. Clifford Geertz, "Deep play: notes on the Balinese cockfight," The Interpretation of Culture (New York: Basic Books, 1973), pp. 412-453. Victor Turner, Dramas, Fields, and Metaphors: Symbolic Action in Human Society (Ithaca: Cornell University Press, 1974).

4. Joseph W. Esherick and Jeffrey N. Wasserstrom, "Acting out democracy: political theatre in modern China," in Jeffrey N. Wasserstrom and Elizabeth J. Perry (eds.), Popular Protest and Political Culture in Modern China (Boulder: Westview Press, 1992). Douglas J. Guthrie, "Political theatre and student organizations in the 1989 Chinese movement: a multivariate analysis of Tiananmen," Sociological Forum, Vol. 10, No. 3 (1995), pp. 419-454. Dingxin Zhao, "State-society relations and the discourses and activities of the 1989 Beijing student movement," American Journal of Sociology, Vol. 105, No. 6 (2000), pp. 1592-1632. 
courses (and sub-discourses), dramaturgies and politics determines who will occupy the centre stage of the public drama, what meanings are constructed, and who can establish legitimacy of their claims at particular moments. In Hong Kong, given the undemocratic institutional set-up, competing ideologies and increasing civil conflicts, a discursive-dramaturgical approach that attends to the negotiated boundary of civil space in the event will well capture the changing state-civil society relationships, which have had repercussions over more recent conflicts over civil rights.

\section{The Discursive Field of Civil Society}

The discursive field of civil society consists of a set of strategic actors, a system of discourses, and a pattern of state-society relations (as configured by the type of state regime) that define the boundary of permissible claims and action over issues of rights and citizenship. Broadly speaking, scholars have distinguished between "rule of law" in liberal regimes and "rule by law" under authoritarian or totalitarian regimes. Hong Kong presents a mixed case. The colonial history left behind a dual legacy of a tradition of law and order and a new discourse of rights and rule of law, the tensions between which are being exacerbated after the handover.

During the period under British rule, in the absence of democracy, the institutional operation of the Rule of Law had remained partial. ${ }^{5}$ There in fact emerged a conscious articulation of law and order as part of the governing ideology as was intensified after the mass riots in the mid1960s. ${ }^{6}$ The Public Order Bill 1967, in particular, became a symbol of colonial power vis-à-vis civil rights. ${ }^{7}$ Struggles against the law in the late 1970 s led to an amended ordinance in 1980 , yet human rights protection on the whole had remained very weak in legal terms at least until the transitional period. ${ }^{8}$ During the 1980 s and the 1990 s, in the context of the "1997" issue, the mixed colonial legacies as well as the rising international norm of human rights became conducive to the development of two conflicting discourses of state-civil society relations: a more rightsbased discourse stressing democracy, rights and rule of law, and an authoritarian discourse stressing stability, control, or law and order. The former, as advocated by the pro-democracy and pro-rights groups, had

5. The Rule of Law was transplanted locally to the extent that a relatively independent judiciary as well as a principle of procedural justice was in operation, and yet it remained partial and deformed in the absence of a democratic legislature.

6. Carol Jones, "Politics postponed: law as a substitute for politics in Hong Kong and China," in Kanishka Jayasuriya (ed.), Law, Capitalism and Power in Asia - The Rule of Law and Legal Institutions (London: Routledge, 1999), pp. 45-68.

7. There had been much resistance against the law, which was somewhat amended in 1981. For further details, see Roda Mushkat, "Peaceful assembly," in Raymond Wacks (ed.), Human Rights in Hong Kong (Hong Kong: Oxford University Press, 1992), pp. 410-438.

8. See Richard Klein, "The empire strikes back: Britain's use of law to suppress political dissent in Hong Kong," Boston University of International Law Journal No.15 (1997), pp. 1-70; Peter Wesley-Smith, "Protecting human rights in Hong Kong," in Raymond Wacks (ed.), Human Rights in Hong Kong (Hong Kong: Oxford University Press, 1992), pp. 17-36. 
been strongly opposed by the Chinese government as well as a conservative alliance of business elites and pro-Beijing groups. In 1989, the suppression of the student movement at Tiananmen Square nevertheless helped place the ideas of rights and rule of law at the centre of political discourse. This was most distinctly shown in the enactment of the Bill of Rights in 1991, as well as the subsequent liberalization of law under the governorship of Chris Patten, such as the Public Order Ordinance and the Societies Ordinance (which formally incorporated a rights component into the law).

Today the two ideologies - of state-society relations in general, and of law in particular - have been at work simultaneously. The Basic Law has included the Bill of Rights, which incorporates the International Covenant on Civil and Political Rights and other human rights covenants. To a large extent, the rule of law remains an institutionalized norm in the judiciary within the common law tradition. Nevertheless, the "law and order" ideology has re-surfaced with enthusiastic support from the government, the conservative elites and the pro-Beijing groups. The SAR government consists of a largely authoritarian structure that is skewed with a conservative stance. ${ }^{9}$ In July 1997, the Beijing-appointed provisional legislature re-amended the ordinances on civil liberties in terms that were stricter than those relaxed during the final years of British rule. ${ }^{10}$ In 1999, in the right of abode dispute, ${ }^{11}$ its turning to Beijing for constitutional interpretation of the Basic Law after the ruling of the local Court of Final Appeal marked the first major sign of a deepening trend of legal and political authoritarianism under its rule. The government justified itself on the grounds of legality, speed and effective social control, in order drastically to reduce the number of mainlanders eligible to settle in Hong Kong. This had roused fierce oppositions from the abode-seekers and the pro-rights groups, which advocated the values of human rights, constitutionality, local autonomy and the rule of law. ${ }^{12}$ State and civil society have been in a tug of war and the space of civil autonomy remains highly contested.

9. For example, the Chief Executive is elected by a small group of conservative elite; within the legislature, councillors returned through democratic elections constitute only one-third of the entire membership.

10. For example, before 1995, the Public Order Ordinance required organizers to get a licence for public assembly. This was removed in 1995. Then in 1997, the amended law included a requirement for a notice of no-objection from the police.

11. The Basic Law originally guaranteed right of abode to all persons of Chinese nationality born to Hong Kong residents. The controversy was raised when, immediately after the handover, hundreds of mainland-born children of Hong Kong residents made a claim to their right of abode. The government curtailed the rights of these people through legal amendment, which then resulted in a tortuous process of legal and political battle.

12. Agnes $\mathrm{Ku}$, "Hegemonic construction, negotiation and displacement - struggle over right of abode in Hong Kong," International Journal of Cultural Studies, Vol. 4, No. 3 (2001), pp. 259-278. 


\section{Triggering Points for the Drama}

In July 1997, the provisional legislature amended the Public Order Ordinance which stipulated, among other things, that marches of more than 30 people or sit-ins of more than 50 people required a seven-day advance notification to, as well as a notice of no objection from, the police. Non-conformance with such legal requirements would subject the protesters to criminal punishment. The police, moreover, were empowered to regulate demonstrations and consider banning them on the grounds of "national security" and "rights and freedom of other people," on top of "public safety" and "public order." Given the terms of the Ordinance, much tension and negotiation had been under way over the boundaries of legality, illegality and legitimacy. In the first three years after the handover there had been more than 6,000 protests and demonstrations, of which around 400 were held without seeking the advance permission required under the Ordinance, but the police had not taken action against these demonstrations. ${ }^{13}$ Practically, the illegal protests, as well as the informal "permission" from the police, had expanded the actual space of civil autonomy beyond the legal confines of the Ordinance. Deep conflicts were nevertheless sparked off during June and December 2000 when the police exercised power in a way that undermined the implicit goodwill as well as exposed the harshness of the law.

The struggle against the Public Order Ordinance was not planned beforehand but broke out "by accident" during a demonstration in June 2000. It was the long and tortuous struggle between the government and the abode-seekers that ignited it, first in June and later in August. In fact, after Beijing's interpretation of the Basic Law in June 1999, there had been continued and increasing conflicts over the issue. Among the abode-seekers, the first major clash with the police took place on 3 December 1999 when, upon the Court of Final Appeal's ruling that Beijing's interpretation was valid and binding (which could lead to their immediate deportation), a few of them fought the police with rocks, bamboo sticks and flowerpots outside the central government offices.

On 25 June 2000, a protest was organized with 1,200 people marching to mark the first anniversary of Beijing's interpretation of the Basic Law. At dawn the next day, a group of protesters including dozens of university students from the Hong Kong Federation of Students, abode-seekers and others stayed on outside central government offices after the overnight demonstration. They refused to leave and scuffles took place when the police used pepper spray to disperse them. Television footage also showed a policeman punching a student in the back of the head. Twelve protesters suffered from mild injuries. The incident was followed in August by arrests of five university students, eight right-of-abode seekers and one citizen. In September five students were arrested, three of

13. According to the government, up till 4 October 2000 , there had been arrests at nine of the 6,600 demonstrations; the police had objected to five planned demonstrations on the grounds of public safety and order, and three of those went ahead after organizers agreed to change the arrangements (SCMP, 4 October 2000). 
whom had already been held over the June episode, relating to an earlier demonstration five months before in April. On 20 April, in opposition to the proposed university tuition fee increase, between 50 and 70 university students marched to the government's headquarters. It started as a peaceful demonstration and scuffles took place only when the students attempted to break through the police lines that barred them from their way to the office of the Secretary for Education and Manpower. The scuffles did not appear to be serious: newspapers said that "slight bodily contact happened." 14 In the end, 16 people including seven university students were arrested over the June and April demonstrations. They were accused of taking part and assisting in the organization of an unlawful assembly, and obstructing police in the execution of their duties. The 16 protesters then faced the possibility of prosecution subject to a maximum penalty of five years' imprisonment.

The use of unusual force by the police in the June episode marked the beginning of the conflicts, but the dramatic heat of the event was suspended as they resorted to the tactic of internal investigation which closed off public scrutiny. The heat was turned on again with the arrests on 15 August and 28 September, which put into public spotlight the immense institutional power of the police as well as the harshness of the Ordinance. The arrests seemed to be motivated: the first took place about two weeks after the attempted suicide at the Immigration Tower of several abode-seekers whose frustrations reached boiling point after a string of recent court defeats. The attempted suicide turned out to be an "arson attack" which had caused serious injuries and deaths and aroused public outrage. While the government might find it an opportune moment to take action against the abode-seekers and the student activists who still supported them, the arrests subsequently developed into a public drama of intense civil conflicts around two related issues: one about the excessive power of the police, and the other about the legitimacy of the Ordinance.

\section{Opposition Discourse and the Performance of Civil Disobedience}

In the first stages, the government had defined the protesters as non-law-abiding citizens, but the opposition discourse managed to gain sway and it soon developed into a successful performance of civil disobedience. Public opinion was not one-sidedly supportive, as evidenced by people telephoning radio programmes to express their disapproval for the students' law-breaking behaviour. Yet by and large, newspaper editorials, commentaries and public opinion surveys showed much sympathy for the students; support was mobilized from academics, ex-student movement leaders, the legal profession, pro-democracy legislators and other civic groups in society. The interesting question is, in view of the competing frame of "illegal" undertaking, how did the opposition discourse come to establish its meaning and credibility? 
The dramaturgy for the discourses of rights and rule of law was grounded at the outset through a more or less consensual construction in the public sphere: the police using excessive force against peaceful demonstrations. ${ }^{15}$ Within the "law and order" framework, the government denied the allegation, portrayed the police as a dutiful agent of law enforcement, defended the use of pepper spray as a minimum use of force relative to the circumstances, and accused the students of a breach of peace involving physical attacks against the police during the scuffles. Yet despite such framing by the government, what made the alternative, consensual construction more plausible was the performance by the protesters - the orderly, non-violent and non-provoking manner in which the rallies were held:

It was on the whole a peaceful, rational protest ... The arrests are undoubtedly an insult to the right to join peaceful demonstrations. ${ }^{16}$

By no stretch of the imagination can pepper spray be described as minimum force ... Against stone throwing mobs it is a necessary protection. But against unarmed student demonstrators? ${ }^{17}$

Other critics went further to juxtapose the peaceful and innocent nature of the demonstration against the "criminal and coercive enactment of law," 18 or "political retaliatory action against student leaders who frequently organize anti-government activities." 19

Besides sympathy from the press, resistance against the police and the Ordinance and support for the arrested protesters also emerged in the form of collective actions. These included a silent rally by about 120 students and activists from organizations such as The Frontier and April Fifth Action on 20 August, and a joint statement of support for the arrested students from 85 academics from several universities on 28 August. The resistance movement gathered momentum around late September and early October when the government pursued the second arrests of five students over an April demonstration. It was at this juncture that a coalition of student activists, pro-rights groups, ex-student movement leaders and other social groups mounted a campaign of civil disobedience against what they called the "evil law."

From a dramaturgical point of view, peaceful illegal protests do not by themselves define a drama of civil disobedience. The Hong Kong Federation of Students had been following the same practice of legal non-cooperation for more than ten years: they only notified the police 24 hours before their assembly without seeking any formal approval. However, their previous protests did not create any dramatic sense of civil disobedience. Neither did the 400 unauthorized protests that took place under the SAR government. What marked the difference between the

15. Ming Pao, editorial, 17 August 2000; Economic Journal, editorial, 28 August 2000; SCMP, editorial, 29 August 2000; Apple Daily, editorial, 28 September 2000.

16. Ming Pao, editorial, 29 September 2000.

17. SCMP, editorial, 6 October 2000.

18. Ming Pao, 22 August 2000.

19. Ming Pao, editorial, 29 September 2000. 
current and the previous protests was the intensity of symbolic meanings conveyed through an ensemble of political, discursive and dramaturgical mechanisms, which paved the way for a battle against the legitimacy of the Ordinance.

First, the government was seen as posing serious threats to civil liberties, both real and symbolic. Right at the outset, the police became an agent of injustice victimizing the student protesters. The students, amidst increasing public sympathy, began consciously to act out the role of victim by calling a radio programme to disclose details of and express worries over the police's harassing phone calls received by their families. The coercive and intimidating image of the police revealed the dangerous potential of the Ordinance, and the capricious arrests further posed a real threat to the rule of law. The arrests of selected protesters on selected occasions after a long lapse of time demonstrated arbitrariness and inconsistency on the part of the police. Particularly worrying was that political considerations might be involved in targeting the students as a pre-emptive measure of threat against unwelcome protests on National Day on 1 October. On 9 October, the Bar Association solemnly presented such concern in a press conference:

An important aspect of the Rule of Law is the concept that all law should be applied objectively, consistently and fairly ... We note with concern ... We are also disturbed by the timing and the manner of the arrest of the university students ... We believe that there are serious issues as to whether the current law ... We strongly urge the Government to conduct a review of the current law ...

With its public image, through the right of abode struggle, of an outspoken, rational and unfaltering guardian of the rule of law as a bulwark against the authoritarian state, the Bar Association's open declaration drummed up further persuasive power for the dramaturgy of victimization of the students by the police. The discursive effects added up to undermine the presumed link between law and legitimacy with regard to the Ordinance as well as the scope of police power allowed under it.

Alongside the police, the Secretary for Security, Regina Ip, acted out the role of an unyielding guardian of law and order in a high profile manner. Discursively, she presented a most succinct interpretation of the idea of law with an emphasis on control and order. In justifying the arrests, she insisted: "It is impossible for the government to condone such open, repeated flouting of the rule of law." Stressing compliance with law and equality before the law, she dared the students to have the courage to face up to the consequences of their actions. Dramaturgically, she personified a staunch, arrogant, authoritarian and yet outspoken bureaucrat and became a popular object of political caricature: she had a stiff look and a callous style; her facial expressions could show a tinge of contempt and smugness; her tone was hard, her words were intimidating, and her stance was never accommodating. Her insistent stress on law and order, as well as her unusually unsympathetic and provocative style, further dramatized and made vivid the threat of state power, and drew increasing public criticism. 
Secondly, on the other side of the drama, illegal protests were legitimately reconciled with the idea of civil rights, which justified further resistance. Emboldened with public support, the students began to shift roles from victim to hero in a performance of civil disobedience. The reconciliation was first made possible by the appeal of peaceful assembly, and it was also justified by the ideas of civil rights, constitutionality, human rights and the rule of law. In terms of dramaturgy, the performance of heroic resistance was effected through speeches, action and other symbolic expressions. In rhetoric, the spirit was one of defiance, selfsacrifice, justice, and rights:

Civil disobedience is a form of protest ... peaceful, rational, non-violent ... We believe in using such a spirit of "self-sacrifice" to expose the unjustness and irrationalities of the laws/ordinances. ${ }^{20}$

We shall not observe any evil law. We did not seek police approval this time and we shall not do so in the future. We are prepared to face the consequences and will exhaust all channels to express our discontent. ${ }^{21}$

Symbolically, some students associated themselves with the thinking of Indian Independence leader Mahatma Gandhi by printing his words on their black T-shirts. In action, they dared to provoke further arrests and prosecution rather than beg for leniency from the police.

The student protesters were not acting alone but were able to demonstrate the power of civil disobedience through other participants and their supporters. On 2 October, HKFS organized an unauthorized march and assembly in condemnation of the Ordinance, which mobilized more than 300 people including pro-democracy legislators, the professional teachers' union, religious groups, women's groups and other advocacy groups. The challenge presented against the authority was direct and daring. For example, legislator Szeto Wah said to a policeman: "Go ahead to register my Hong Kong ID! I am participating in an illegal assembly." Many protesters chanted "Arrest me! Arrest me!" The police took no action except to issue verbal warnings, but these were simply drowned out by the chanting. ${ }^{22}$ Clearly, street protests occupied the centre stage of the drama.

Riding on such sentiments of support, ex-student movement leaders pronounced that another larger-scale (illegal) protest was being planned. A few days later, the Department of Justice announced that it would not prosecute the people arrested over the April protest, while the June protest was still left undecided. Despite this move of concession, resistance did not die down but, to the contrary, was emboldened. As one ex-student movement leader proclaimed: "The power of civil society has been shown! We shall continue the struggle!" An opinion poll also showed that public support was on the side of the pro-rights alliance.

20. HKFS, 27 August 2000.

21. Movement organizer, SCMP, 9 October 2000.

22. Alvin So, "Social protests, legitimacy crisis, and the impetus toward soft authoritarianism in the Hong Kong SAR," in Lau Siu-kai (ed.), The First Tung Chee-hwa Administration: The First Five Years of the Hong Kong Special Administrative Region (Hong Kong). 
More than half of the respondents (56.7 per cent) did not agree to prosecution, compared to 20.4 per cent who agreed to it; 42.7 per cent were in favor of cancelling the system of approval by the police, compared to 26.8 per cent who were against it. ${ }^{23}$

On 8 October, more than 1,000 people joined in an illegal protest already planned by the ex-student movement leaders. They marched from the city hub to the central government office, burned a mock copy of the Public Order Ordinance and chanted slogans that drowned out the warnings of the police: "Down with the Public Order Ordinance. Hand me back my civil rights." These symbolic acts were deliberated to convey a sense of public rage, to defy the authority of the police and to challenge the Ordinance in a high-profile manner. The performance of civil disobedience was not only persuasively conducted by the student activists, but also picked up a dramatic force through the participation of other people. This presented a strong and direct challenge to both the enforceability and the legitimacy of the Ordinance. In public discourse, the power of the performance registered a remarkable effect that pointed to an urgent need to review or amend the Ordinance:

The power of civil disobedience lies in making laws ineffective ... Laws that cannot be enforced should be amended or even removed by the government ... a strong public outcry for a review of the Public Order Ordinance. ${ }^{24}$

This particular law has been decisively held in contempt, not by a group of determined activists alone but also with the backing of majority opinion ... This ordinance is unenforceable, and that is surely the most compelling argument for amendment. $^{25}$

Thirdly, the students possessed a special, almost sacred status that added symbolic weight to the civil struggle, the result of public construction via the media and their supporters. Given their role as students as well as their political conviction as demonstrated in previous events, ${ }^{26}$ they largely succeeded in showing that their involvement in political and civil struggle was not motivated by any self-interest. Hence public discourse, opinion surveys and supportive collective action focused only on students to the exclusion of other non-student arrestees. University heads called for lenience to the students, and more than 500 university professors petitioned against their prosecution in a joint statement: "We believe that while students should attend to their studies ... they should neither tolerate nor turn a blind eye to social injustices." The narrative celebrating student-hood or student activism as a symbol of idealism was given a most succinct account in a newspaper editorial which characterized students, especially student leaders, as generally embodying the "conscience of society": "Students are pure, empathetic and righteous,

23. Apple Daily, 6 October 2000.

24. Economic Journal, editorial, 9 October 2000.

25. SCMP, 26 October 2000.

26. The student leaders, especially the president of the Student Union of the University of Hong Kong, were cast as playing an outstanding role on the side of justice in the earlier scandal about an alleged infringement upon academic freedom in the University. 
and they hate vices. Student leaders often represent and reflect the superb qualities of the students; they embody and reflect the conscience of society ..."27 Most significantly, there is a symbolic link with the long tradition of student activism against social injustice and political repression. Ex-student movement leaders initiated a campaign in support of the students: 370 names were collected from the past leaders and more than 1,000 people joined the "march against repression of the student movement" on 8 October. An organizer described it as an historic and unprecedented landmark of collective unity in the history of the student movement. During the march, prominent ex-student movement leaders spoke out on their acts of civil disobedience against colonial repression 20 years ago that finally led to the amendment of the Public Order Ordinance in 1980.

In sum, a campaign of civil disobedience was effectively conducted through scripting, role enactment, symbolic expressions and activation of tradition within the discourses of rights, rule of law and constitutionality. Through their civic action, the protesters had defied the law and asserted their rights; in their demands, they urged against prosecution of the students and called for legal amendment. The scale of mobilization might not be large, but the momentum was increasing, and the symbolic meaning was conspicuous.

\section{Release of Dramatic Suspense and the Lost Appeal of Civil Disobedience}

On 25 October, the Department of Justice finally decided not to prosecute the protesters over the June demonstration. No official statement was provided. Earlier, regarding the April demonstration, it was only briefly explained that the decision of non-prosecution was reached on legal grounds after having "reviewed all the available evidence" and considered "all the circumstances." The real intention of the government could not be directly inferred from its brief remarks, but it was clear that it scrambled to maintain an image of a strong government which did not simply yield to public pressure with the effect of rendering the law unenforceable. Thus when critics welcomed it as a right decision based on a discretionary consideration of public pressure in favour of lenient enforcement of law, ${ }^{28}$ the Department of Justice denied this and stressed only legal considerations. It was indeed possible that the Department did not see a strong case in it, especially given an independent judiciary that followed the rule of law. Yet presumably, if there were insufficient legal grounds, this should simultaneously call into question the rationality of the Ordinance itself, for the demonstration did in fact break the law. The government, however, remained adamant about keeping the law unchanged.

In any case, as far as dramaturgical and political effects were concerned, two interrelated processes were at work to bring about a new turn 
that worked to the advantage of the government. First, in public discourse, the decision by the Department of Justice served to undermine the continued appeal of street activism. Secondly, on the side of the government, it sought to defuse further resistance while standing firm as the die-hard guardian of law and order, a role taken up primarily by the Secretary for Security in her defence of the Ordinance. These made way for a re-scripting process whereby street activism gave way to institutional politics as the new centre stage. In the rest of the article, discussion will focus on, first, the wider symbolic and institutional contexts that enabled and constituted the shift, and secondly, the symbolic and political effects of the government's moves that defined the final outcome.

The government's decisions not to prosecute might be expected to demonstrate the political success of the opposition movement, and yet the movement was not empowered. In effect the decisions by the Department of Justice worked to release much of the dramatic tension held up in the heated campaign of resistance. In early October, the tension was crystallized around the suspense of the likelihood of prosecution of the arrested students over the June demonstration. Once the government dropped the case, the suspense was released, and the "evilness" of the Ordinance was drastically diminished. This could partly explain why the anti-Ordinance campaign lost much steam in the second stage:

[I] believed that the "demand against prosecution of students" could mobilize the most social support at that time ... However, when the government decided not to prosecute the students, the movement for amendment of the Public Order Ordinance came to a crossroad, because the rallying point for the campaign was lost (or it could be regarded as a success). ${ }^{29}$

In such a context, even though student protesters vowed to fight on until the "evil law" was rectified, while pro-rights groups and democratic legislators called on the government to review and amend the Ordinance, collective action in the form of open petition or large-scale protest against the Ordinance died down. ${ }^{30}$

Among other things, the end of the anti-prosecution campaign set in process a concerted call to turn to institutional procedure for a legislative resolution, especially among the pro-rights legislators, the legal profession and the press. In fact, as early as the first week of October, there was news of the Democratic Party legislators working on a joint proposal for legal changes with other civic groups ${ }^{31}$ and planning to move a private member's bill to amend the ordinance via the legislature. Politically it seemed to be a logical course to take, but after the government dropped

29. Tsoi Yiu-cheong, an organizer of the campaign (Ming Pao, 6 January 2001).

30. On 6 November and on 20 November, HKFS mobilized, respectively, fewer than 40 and about 70 people in an anti-Public Order Ordinance demonstration, which was compared to the high tide of more than 1,000 in early October.

31. The Human Rights Monitor, the Human Rights Commission, HKFS, The Frontier, the Association for Democracy and People's Livelihood and the Democratic Party jointly suggested retaining a notification system without decriminalizing the failure to notify, and recommending specific safeguards against possible abuse of power by the police. 
the case, the shift was also mediated through a process of meaning reconstruction in public discourse that began to denigrate street activism. A deeper look at the multiplicity of sub-discourses reveals how public sympathy for the students embodied nuanced differences over the ideas of rights, civic propriety and student-hood which both reinforced and fragmented the narrative of civil disobedience. For instance, there was a fine line between asking the government for lenience and forbearance and a heroic assertion of rights and resistance. While the students as well as their supporters adhered to the latter, academics suggested that "any such decision [of non-prosecution] should be based on leniency towards the students," and an editorial in SCMP wrote,

... at an age when rebellion is to be expected. Since there is a lot at stake in their futures, and because they are more than likely to become tomorrow's respectable and law-abiding citizens, it is unfortunate that the police did not feel disposed to show a little more forbearance. (6 October 2000)

In this account, forbearance towards the students was the theme, and students were conceived not so much as the "conscience of society" in a discourse of heroic resistance, as a particular rebellious age group and future respectable and law-abiding citizens in a framework of law and order. This account exemplified how underlying the same demand for non-prosecution could be a discourse that added weight to the opposition discourse at one point of time and yet diverged from it once the cause for sympathy (the possibility of prosecution) was removed:

Activism has set that process in motion ... However ... the SAR is founded on the rule of law and thrives because of it. People cannot pick and choose which sections of the law they want to obey. When laws are repressive, they can be challenged, but a free society has legal means to bring about change. That is the better cause. In a democracy, public pressure should influence government without resort to law-breaking. (26 October 2000)

The idea was that street activism had played a significant role in stage one but needed not outlive it. A discourse of rule of law presuming institutional pluralism as well as an idea of law-abidingness was at work to underscore a necessary transition from activism to legislative politics. Likewise with an appeal to calmness and reason, the editorial in Ming $P a o$ proposed that the government "take back the initiative by proposing a legal review ... with a cool-off period of two to three months first, so that we can have a rational and objective discussion" (26 October 2000). The underlying ideas were rational discussion versus broil, institutional order versus unresolved chaos.

While the government had remained adamant about keeping the law unchanged, the chair of the pro-Beijing Democratic Alliance for the Betterment of Hong Kong had all along insisted that the Ordinance was no evil law in itself: "It is [therefore] an unfounded and unfair accusation to say that the Provisional Legislative Council has restored a draconian colonial law ... People should target their anger at the selective arrests, 
rather than the law itself." 32 In the midst of increasing calls for a legislative resolution in public discourse, what happened was that the government later appropriated the appeal to reason and usurped the idea of legal review while standing firm against any amendment of the law.

The "Law and Order" Discourse and the Strategy of Re-scripting by the Government

The next set of strategic moves by the government was taken up primarily by the Security Bureau under Regina Ip. Under the given institutional structure, it was she who, with her frame of mind and domineering profile, personified the law and order ideology, seized back the centre stage of the drama from street activism to institutional politics, and finally achieved an ironic success for the government.

Immediately after the Department of Justice announced the second decision of non-prosecution, the police issued a letter to the arrested people affirming the criminal nature of the demonstration and warning them of future prosecution in case of similar undertaking. The Secretary for Security added: "No one is above the law. Just because some people are not prosecuted this time, it does not mean they would be exempt from prosecution forever." Control over demonstration was justified on the grounds of public order (such as the prevention of disruption to traffic), and the harshness of law on the grounds of deterrent effect: "There is a need to keep the law harsh enough to have a deterrent effect if you hope the people will observe it. [The Ordinance] only targets participants who knowingly take part in an unauthorized assembly." ${ }^{33}$ It followed that while the law should be strict, application of it could be lax. In this connection, the Secretary for Security openly called students a "headache," 34 and senior police officers privately branded activists as "troublemakers" and were concerned about the demoralizing effect of non-prosecution on frontline police. In brief, the "law and order" discourse by the government stressed the need for public control, maintained the harshness of law in principle, allowed much discretionary power by the police in practice, and conceived the activists as unruly troublemakers rather than citizens with legitimate rights. It enabled the government to defend the Ordinance, which also had the open backing from Beijing. ${ }^{35}$ The stern delivery of the discourse of law and order together with the words of warnings added up to present a dramaturgy of a government willed to the maintenance of law and order under the existing Ordinance.

Within civil society, although HKFS continued with their smallscale protests in a much lower profile, political calls for a legal review had been mounting. It was at this time of an unresolved deadlock that the

32. Ming Pao, 10 October 2000.

33. It was quoted in SCMP, 26 November 2000.

34. Ming Pao, 5 November 2000; SCMP, 5 November 2000.

35. The position of Beijing was expressed by a vice-director of the legal affairs commission of the National People's Congress Standing Committee in early December (SCMP, 7 December 2000). 
Secretary for Security seized back the initiative by making a new public appeal to reason and launching a performance of sham public consultation and procedural resolution. The appeal to reason was in fact first proposed by the media but was appropriated by the government in a more favourable public climate. In late October, on RTHK radio, the Secretary for Security challenged the student activists to a debate on the Ordinance in the name of reason: "We are not convinced by the so-called viewpoints presented so far. Slogans are not truths and resorting to so-called civil disobedience is no good way to resolve a problem ... I want them [the students] to see us, and convince us." Among the press, there were opinions along the same line, "the fundamental issues surrounding the controversial Public Order Ordinance have become muddled by activism and exaggeration ... too much sensationalist slogan-shouting from those who oppose the Ordinance." ${ }^{36}$ The political climate was indeed undergoing changes, not only in public discourse but also among the activists. For example, at this time, HKFS was also working on a joint proposal for legal amendment with other groups which had already scheduled to meet the Secretary for Security on 25 November. Although the joint proposal was originally an attempt to take the initiative for change from within civil society, it appeared that the government's appeal could incorporate such civil society initiative under the new frame of debate and dialogue. There was a brief interlude when the heat of resistance was cooling off in the public.

In an undemocratic structure where the government had an upper hand, the pro-rights groups and the public were expecting it at least to perform a ritual or dramaturgy of sincere consultation. The heat of the drama increased again when the Secretary for Security failed on this expectation and suddenly proposed to table a motion in support of the Ordinance in the Legislative Council on 22 November. The release of this news was accompanied only by a brief and ritualistic statement by a government spokesperson. Pro-Beijing parties hailed it as a sign of restoration of reason and order after the prolonged process of bickering. However, pro-democracy legislators saw it as a pre-emptive strike to obtain legislative support before genuine public consultation could begin. They also found in it a failed dramaturgy for the claim of dialogue and consultation and criticized the Secretary for Security as "showing no sincerity, not even bothering to play up hypocrisy, and lacking an open mind." 37

Politically, in the specific dispute over the Public Order Ordinance in 2000, the move produced two effects: it rejuvenated discontents against the government, but it also shifted the scene further away from the street to the legislature. On one level, it played to sheer institutional power. Given the skewed structure of the legislature, which consisted mostly of conservative and pro-Beijing elites, it was calculated that the motion would be passed with a simple majority. On another level, it involved dramaturgical considerations about legitimacy and perform-

36. SCMP, 29 October 2000.

37. SCMP, 23 November 2000. 
ance. The intended dramaturgy was to present a strong and effective government taking the initiative to resolve the disputes through reasoned debates, public consultation and legislative support. There was a charge of hypocrisy, but the government later somewhat diluted it by conceding, upon the request of the Legco House Committee, to adjourn the debate by about a month as a conciliatory gesture to listen to public opinion. With the adjournment, despite a lack of trust in the government, the pro-rights groups unwittingly played a participatory role in the consultative process. (For example, when the government proposed to sponsor the motion, the Human Rights Monitor proclaimed there would be a resort to civil disobedience, but later, with the adjournment, the idea was not put into action.)

Moreover, it was with the shift to the theatre of institutional consultation that legislators' voices and public expressions of opinion from both sides were mobilized via different channels. During this period, legal discussion by the Bar Association, legal scholars and government officials abounded in the newspapers. The conservative Liberal Party began to voice its opinions in newspaper columns, toeing the government's line in stressing a balance between individual freedom and political order and discrediting the pro-democracy legislators' participation in the lawbreaking protests. In the meantime, the security panel of the Legislative Council held several open sessions to hear views from the public. It was through these sessions that a critical mass in support of the government's position was mobilized from among the pro-Beijing network. Most remarkably, right from the first session, dozens of groups and some individuals made a chorus of support for the government's noamendment stance: "Law is made to protect the interests of the majority"; "I think the law is not too harsh, but too lenient. Even legislators came out to challenge the law"; "Some people will resort to arson attacks if the controls are eased." 38 Moreover, business groups such as the Hong Kong Chamber of Commerce also openly supported the government. The pro-rights groups voiced their dissent in these open sessions as a counterbalance, which, despite their protest against "sham consultation, real dictatorship," ironically reinforced the drama of reasoned debate and public consultation. All these had enabled the Secretary for Security smugly to proclaim triumph and crown the government as the agent of successful re-scripting by taking back the initiative via the motion. ${ }^{39}$

Finally in the Legislative Council meeting, the Secretary for Security commanded the stage of legislative debates and thereby seized media attention by giving a well-rehearsed, provocative and elaborate speech that was dense with uncommon metaphorical references about chaos, disorder and danger associated with unregulated and emotional mass gathering. She cited examples locally and overseas, including the most recent anti-globalization protests in Seattle and Melbourne. As expected, with the support of the conservative elites and pro-Beijing groups, the

38. SCMP, 19 November 2000.

39. Economic Journal, 18 December 2000. 
motion was passed. Outside the Council building, emotions ran high as about 300 people backing the Ordinance in its entirety waged a noisy verbal war with 40 opponents demanding the law be amended. As the whole drama was drawing to a close with the anticipated political outcome, such a scene of emotional flickering was like amateurs shouting for the sake of shouting.

Was it a success of the government? Politically, it was a victory that was ensured by the institutional structure. The law remained unchanged, continuing to pose unwarranted legal limits to civic freedom. Yet symbolically, it was at best an ironic success that put the state-society relationship on an increasingly tenuous course. On a most manifest level of meaning construction, the motion debate gave the government a chance to present a performance of public and legislative quasi-consultation and to demonstrate its ability to mobilize support from the conservative groups. This was necessary to endow the law with a certain degree of legitimacy. The Secretary for Security even labelled the opposition camp as "an extremely small minority of people voicing out their biased and extreme opinions." ${ }^{40}$ However, on a deeper level of perception of state legitimacy, public critics were critical of the confrontational stance and the tactic of polarization of the government. The opposition side found the whole process "biased," "antagonizing" and indicative of "fear-mongering," and they saw in it a self-directed show of victory by the government: "The government poising itself in such a commanding way, with the endorsement from the legislature, to declare victory" 41 ; "for the moment, the government has won a battle. But the war goes on." 42 Although the law remains the same as before, the state-society relationship has never been the same again. On the one hand, the government has emerged increasingly wedded to the maintenance of law and order, as shown in more recent conflicts involving arrests and prosecution under the Public Order Ordinance in May 2002. On the other hand, the contenders, having experienced both the power of organized resistance as well as frustrations with the government, continue their resistance with old and new tactics.

\section{Concluding Remarks}

The aim of this article is to delineate the negotiated space of civil autonomy in post-handover Hong Kong through the contingent interplay of law, discourse, dramaturgy and politics. It has taken the Public Order Ordinance dispute in 2000 as the first major test case of civil conflicts in the shadow of the right of abode struggle. In the event, civil autonomy had been a contested issue involving considerations of rule of law, rights, civic propriety, state legitimacy and the construction of particular identity (such as student-hood). Given the multiplicity of discourses and sub-dis-

40. Ming pao, 22 November 2000.

41. Economic Journal, 22 December 2000.

42. Democratic Party chair, SCMP, 26 December 2000. 
courses, citizenship practices and public criticisms opened up a contested space for political resistance and meaning reconstruction. On the part of the government, it might wish to strive for control and stable governance under the ideology of law and order. Yet ironically it was the government itself which further politicized and radicalized the society. The capricious arrests by the police had posed threats to the rule of law; the process of consultation and legal review turned out to be a fake dramaturgy that reaffirmed state power. Ultimately ideological differences were at stake: respect for a rights-based discourse of rule of law versus the assertion of political and legal authoritarianism. Thus in the final moment, despite its political victory, the success of the government under the "law and order" framework had built on a very fragile basis. The pro-rights groups saw in it a blunt, stubborn and imposing style of authoritarianism as manifested in the ways government officials launched a biased consultation, in the manners they delivered themselves in the public and in the legislature, and in their determination not to amend the Ordinance regardless of protests and opposition. The state-civil society relationship became more delicate, which might easily erupt into further civil conflicts. This has indeed been the case already, as revealed in more recent conflicts including most notably that over the legislation of Article 23 (on national security) of the Basic Law.

In December 2002, tensions were escalating leading to tens of thousands of citizens marching in opposition to the proposed law, which was followed by another public rally by the pro-Beijing alliance one week later. The scale of political mobilization was the largest since the Tiananmen Square incident in 1989. Then on 1 July 2003, about 500,000 people joined in another, even more spectacular march against the government. If the government was able to seize the centre stage back from street activism to institutional politics in 2000, it would appear that by 2003 street activism was returning with all the more fervour to confront institutional power head-on. Politically, the march was a successful demonstration of civic power against the state resulting in the resignation of two ministers including the Secretary for Security. Still, the full meanings and significance of the event were yet to be further revealed, negotiated and reconstructed. For example, who were the chief villains or the culprits? How were the resignations performed and what did they signify? Were these the answers to the outcries of the people in the march? How did Beijing help stage a scene of support for the Tung administration in the aftermath of the fiasco? If, back in 2000, the SAR government was able to present a dramaturgy of restoration of "law and order" with ironic success, the question of whether or not it can establish a credible dramaturgical line to restore legitimacy amidst the mounting calls for democracy and civic liberty would be a fruitful line of inquiry for future research. 